\title{
Does Lapatinib Increase Pulmonary Toxicity when Concurrently Used with Radiation Therapy? An Experimental Study with Wistar-Albino Rats
}

\author{
Ozlem YETMEN DOGAN ${ }^{1}$, Elif GUZEL ${ }^{2}$, Ilker COBAN ${ }^{3}$, Oner SUZER ${ }^{4}$, Nuran BESE ${ }^{5}$ \\ ${ }^{1}$ Saglik Bilimleri University, Kartal Dr. Lutfi Kirdar Training and Research Hospital, Department of Radiation Oncology \\ ${ }^{2}$ Istanbul University-Cerrahpasa, Cerrahpasa Faculty of Medicine, Department of Histology and Embryology \\ ${ }^{3}$ Yeditepe University, Faculty of Medicine, Department of Physiology \\ ${ }^{4}$ Istanbul University-Cerrapaşa, Cerrahpasa Faculty of Medicine, Department of Medical Pharmacology \\ ${ }^{5}$ Acıbadem University, Acıbadem Maslak Hospital, Department of Radiation Oncology, Istanbul,TURKEY
}

\begin{abstract}
Lapatinib is an oral receptor tyrosine kinase inhibitor which has shown activity in the treatment of metastatic breast cancer. There is no data regarding the side effects of combination of radiotherapy and Lapatinib. 40 female Wistar-albino rats (WAR) were divided into 4 groups; G1 did not receive any treatment, G2 received radiotherapy to whole thoracic region, G3 received Lapatinib without radiotherapy, G4 received Lapatinib with radiotherapy. A total dose of 30 Gy in 10 fractions was given to both lungs. Lapatinib equivalent to $1500 \mathrm{mg} /$ day were calculated according to the mean weight of rats, orally administrated. A comparative analysis was performed by scoring the pulmonary injury between 0 and 3 according to the infiltration of inflammatory cells into the alveolar spaces, alveolar wall thickening and architectural deformation across the entire lung section. In G2 inflammatory cell infiltration, fibrosis with damage to lung structure andformation of small fibrous masses were observed. Alveolar septa were significantly thicker than $G 1$ ( $p \leq 0.001$ ), which revealed totally normal pulmonary structure. G3 showed minimal alveolar septal thickening and infiltration of inflammatory cells into the alveolar spaces which was not significantly different than G1. Histopathological findings in G4 were similar to those in G2 and statistically different when compared with the $\mathrm{G} 1$ and $\mathrm{G} 3$ ( $\mathrm{p} \leq \mathrm{0.001)}$. In this experimental study it has been shown that addition of Lapatinib to radiation did not increase RIPF in rats.
\end{abstract}

Keywords: Breast cancer, Lapatinib, Radiotherapy, Wistar-albino rats

ÖZET

Radyoterapi Tedavisi ile Eşzamanlı Lapatinib Kullanımı Akciğer Toksisitesini Artıır mı? Wistar-Albino Sıçanları ile Deneysel bir Çalışma

Bir oral tirozin kinaz inhibitörü olan lapatinibin metastatik meme kanserinde etkisi gösterilmiştir. Ancak radyoterapi ile Lapatinib birlikte kullanılışı ile ilgili yeterli veri yoktur. Bu çalışmada 40 adet Wistar-albino cinsi sıçan 4 gruba ayrıld; Grup1 (G1) herhangi bir tedavi almadı, Grup 2(G2) tüm torasik bölgeye radyoterapi aldı, Grup 3 (G3) radyoterapi olmadan Lapatinib aldı, Grup 4 (G4) radyoterapi ile Lapatinible birlikte aldı. Her iki akciğere 10 fraksiyonda toplam 30 Gy doz verildi. Oral olarak uygulanan Lapatinib, sıçanların ortalama ağırlığına göre 1500 mg / güne eșit hesaplandı. Çalışmada analiz, enflamatuar hücrelerin alveoler boşluklara infiltrasyonuna, alveolar duvar kalınlaşmasına ve tüm akciğer kesiti boyunca deformasyona göre 0 ve 3 arasında pulmoner hasarı skorlamak suretiyle yapıldı. G2'de inflamatuar hücre infiltrasyonu, akciğer yapısına zarar veren fibrozis ve küçük fibröz kitlelerin oluşumu gözlendi. Alveoler septa yapısı, tamamen normal pulmoner yapı gösteren $\mathrm{G} 1$ 'den ( $\mathrm{p} \leq$ 0.001) anlamlı derecede daha fazlaydı. G3'de ise G1'den farklı olmayan, minimal alveolar septal kalınlaşma ve inflamatuar hücre infiltrasyonu gösterildi. G4 ve G2 de histopatolojik bulgular benzer olmakla beraber, G1 ve G3 ile karşılaştırılığında istatistiksel olarak farklıydı ( $p \leq 0.001)$. Bu deneysel çalışmada, Lapatinib'e radyasyon eklenmesinin sıçanlarda radyasyona bağlı pulmoner fibrozisinde artışı göstermediği görülmüştür.

Anahtar Kelimeler: Meme kanseri, Lapatinib, Radyoterapi, Wistar-Albino sıçanlar 


\section{INTRODUCTION}

Breast cancer is the most commonly diagnosed cancer among woman in the world. Radiotherapy has a significant role in the treatment of breast cancer as well as other treatment modalities like surgery and systemic treatments. ${ }^{1,2}$

Lung is one of the most radiosensitive organ, yet is frequently irradiated as part of treatment for cancers of the breast. In human the early phase of radiation effects in lung becomes apparent at about 1-3 months after radiotherapy, tissue histology shows an increase in type II pneumocytes and a decrease in parenchymal cells and surfactant concentrations. At this phase inflammatory cells are present in the tissues and alveolar macrophages are prominent. Pneumonitis generally subsides after several weeks and is followed by chronic inflammation and fibrosis that develops months or years after irradiation. In this phase, vascular damage and collagen deposition become apparent. ${ }^{3}$ Data from animal and human studies indicate that vascular injury and coagulation cascade, cellular adhesion molecules, proinflammatory and profibrotic cytokines and oxidative stress all seem to have vital roles in the development of radiation fibrosis., ${ }^{4,5}$ Studies have shown that radiation-induced pulmonary fibrosis (RIPF) is a dynamic process characterized by a constant remodeling of fibrous tissue and long term fibroblast activation. ${ }^{4-7}$

The epidermal growth factor receptor family of proteins, including Erb B1/EGFR/Her 1, Erb B2/ Her 2/neu, Erb B3/Her3, and Erb B4/Her 4, have been reported to play a role in tumorigenesis and regulate epithelial cell proliferation, survival and differentiation. ${ }^{8}$ Her 2 and EGFR play an important role and positivity in breast cancer cells associated with poor prognosis and unfavorable to therapy. Ongoing clinical trials are investigating the benefits of new targeted therapies, including Erb B and tyrosine kinase inhibitors and antiangiogenesis. These targeted therapies may carry a potential risk for additional pulmonary and cardiac toxicity, in association with radiotherapy. ${ }^{8,9}$

Lapatinib, is a small-molecule tyrosine kinase inhibitor that binds reversible to cytoplasmic ATPbinding site in the kinase of EGFR and HER 2, thus inhibiting receptor phosphorylation and ac-

\begin{tabular}{|ll|}
\hline Table 1. Distribution of the groups \\
\hline Groups $(G)$ & \\
G $1(n=10)$ & Control \\
G $2(n=10)$ & Radiotherapy \\
G $3(n=10)$ & Lapatinib \\
G $4(n=10)$ & Radiotherapy+Lapatinib \\
\hline
\end{tabular}

tivation. ${ }^{10}$ In a randomized phase 3 study, lapatinib added to capacitabine improved the time to disease progression compared with capecitabine alone in the metastatic breast cancer. ${ }^{11}$ Preclinical data suggest that lapatinib may have a radiosensitizing effect on the metastatic breast cancer cells to the brain which may lead increased side effects when combined in the clinical setting. ${ }^{12,13}$ There is not enough data regarding the late effects of lapatinib when used with RT. In this experimental study we evaluated if concurrent or sequential administration of lapatinib has any impact for the development of radiation induced pulmonary fibrosis (RIPF) in rats. Lung is chosen as it is one of the most radiosensitive organ.

\section{MATERIALS and METHODS}

Fourty femaleWistar albino rats weighting approximately $200 \mathrm{~g}$ were used in this study. Animals, produced, bred and housed in Istanbul UniversityCerrahpaşa Medical School, Experimental Animal Breeding and Research Laboratory of Medical School in Istanbul. The study was approved by the local ethics committee of Istanbul University Animal Experiments with the decision no. 41 on 24.09.2008.

Five animals were housed per cage and maintained under identical conditions with food and water provided ad libitum. All experiments were carried out in compliance with the regulations of the institution and the $3 \mathrm{R}$ (reduction, replacement, refinement) ethical guidelines. Wistar albino rats were randomized into 4 experimental groups. The first group of rats (Group 1), did not receive any treatment. The second group of animals (Group 2) had irradiation to whole thoracic region. The third group of animals (Group 3) had lapatinib without thoracic irradiation. The fourth group of animals 


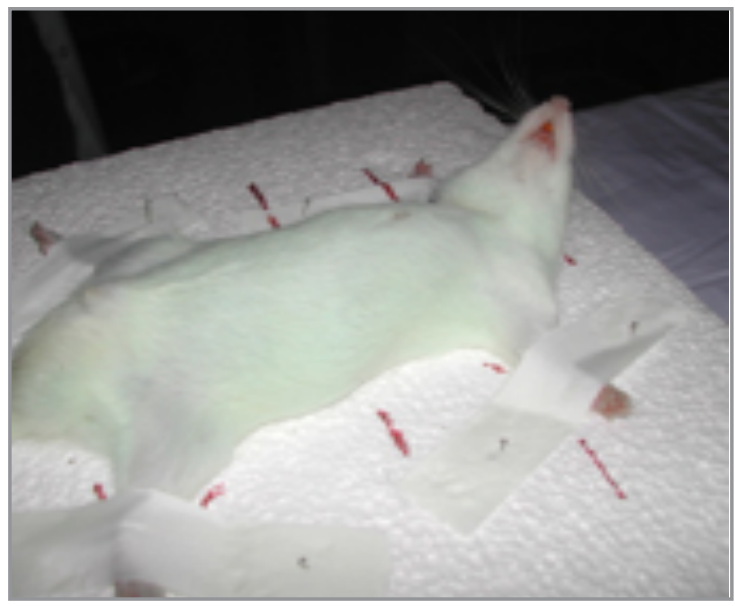

Figure 1. The simulation of a rat

(Group 4) had lapatinib in addition to thoracic irradiation (Table 1 ).

All rats in each group were irradiated to whole thoracic region with Cobalt 60 unit at Radiation Oncology Department. Whole lungs of the rats were simulated and marked prior to irradiation. Animals were anesthetized with an intramuscular (IM) injection of Ketamine-HCL at a dose of $50 \mathrm{mg} / \mathrm{kg}$, prior to simulation and irradiation. Animals were held securely on a foam holder at supine position and plastic bandages were used to immobilize the thoracic region during irradiation (Figure 1-2). A total dose of $30 \mathrm{~Gy}$ in 10 fractions was given to both lungs with an anterior field at $2 \mathrm{~cm}$ depth.

Lapatinib equivalent to $1500 \mathrm{mg} / \mathrm{day}, 60 \mathrm{~kg}$ adult dose, were calculated according to the mean weight of rats, orally administrated with a feeding tube twice daily including the weekends until the WAR were sacrificed. The animals were anesthetized and sacrificed with cervical dislocation, 12 weeks after the completion of irradiation.

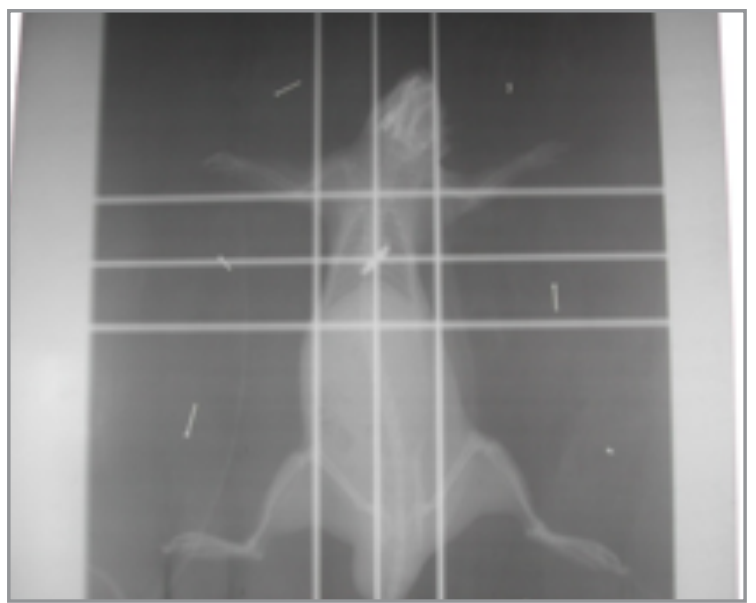

Figure 2. The simulation film of a rat which shows the irradiation field including the whole lung volume

Histological analysis was carried out on wholelung, paraffin sections (5 $\mu \mathrm{m}$ thick) that were stained with hematoxylin-eosin and Masson's trichrome. Lung sections were assessed and grade of fibrosis was scored for each section according to a scoring system modified from Ashcroft et al. andDowning et al. ${ }^{14,15}$ A semi-quantitative comparative analysis was performed among 4 groups by scoring the pulmonary injury between 0 and 4 according to the infiltration of inflammatory cells into the alveolar spaces, alveolar wall thickening and architectural deformation across the entire lung section. Each criterion had a possible score of 0 to 4 , where 0 no injury; 1 minimal injury, 2 mild injury, 3 moderate injury, and 4 marked injury. The total lung injury score was calculated by summing the scores of these three parameters. Slides were then examined and photographed by two independent histologists in blinded fashion under light microscope (BX61, Olympus, Japan) attached with a digital camera (DP72, Olympus, Japan)(Table 2).

\begin{tabular}{|llllll|}
\hline \multicolumn{1}{|l}{ Table 2. Histological Scoring Criteria for Lung Fibrosis } \\
\cline { 2 - 6 } Parameters & $\mathbf{4}$ & $\mathbf{3}$ & $\mathbf{2}$ & \multicolumn{1}{c|}{ Scores } \\
\hline Infiltration of inflammatory cells & Marked injury & Moderate injury & Mild injury & Minimal injury & No injury \\
Alveolar wall thickening & Marked injury & Moderate injury & Mild injury & Minimal injury & No injury \\
Architectural deformation & Marked injury & Moderate injury & Mild injury & Minimal injury & No injury \\
across the entire lung section & & & & & \\
\end{tabular}



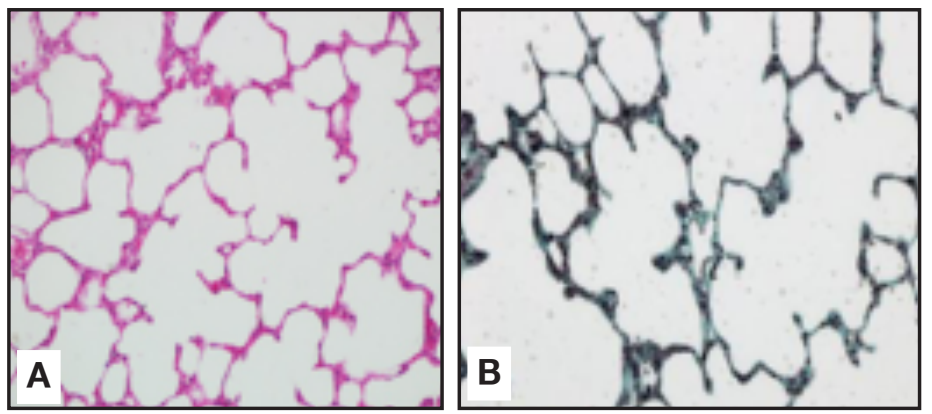

Group 1 (A, B): Control; the alveolar walls of the

lungs of the control rats are very thin.
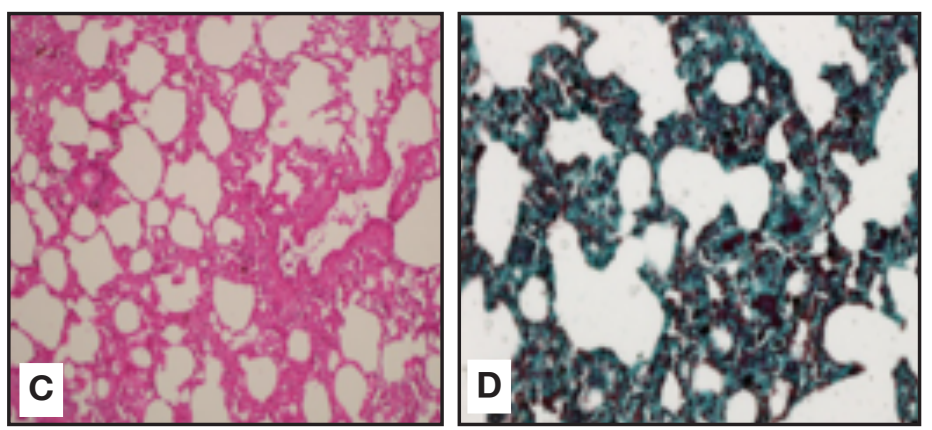

Group 2 (C, D): RT; areas of intensive fibrosis and thickened alveolar walls are the consequences of RT
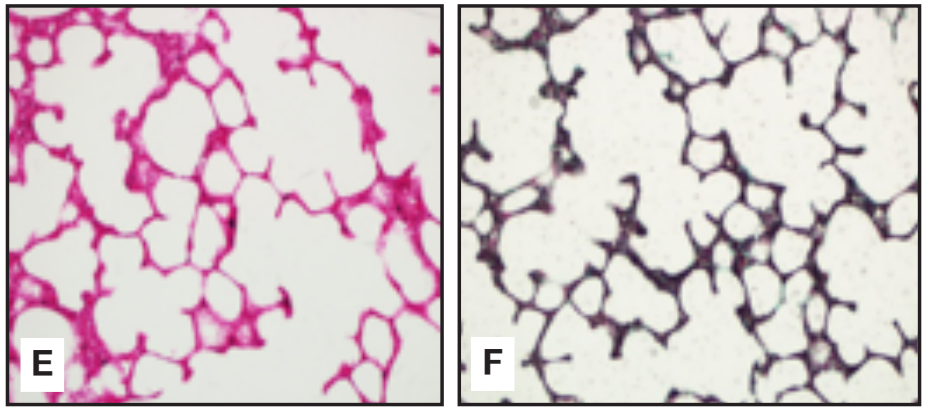

Group 3 (E, F): L; areas of intensive fibrosis and thickened alveolar walls are the consequences of RT
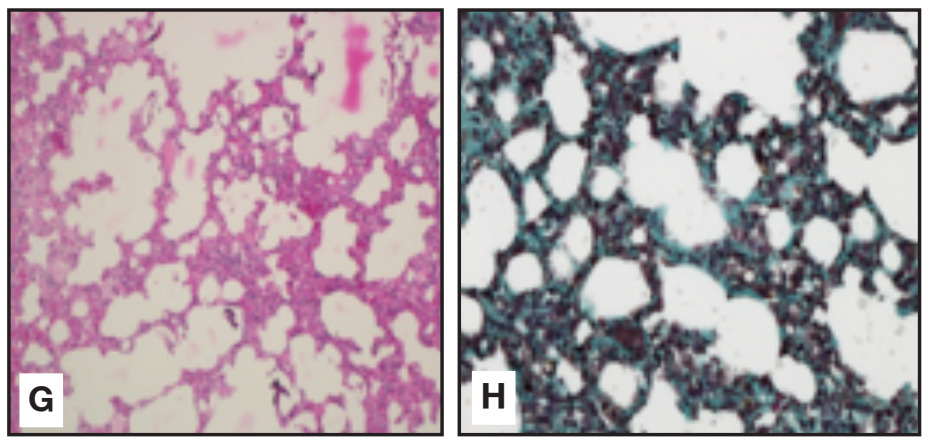

Group 4 (G, H): RT+L; alapatinib when combined with RT did not worsen the effects of RT on lung.

Figure 3. Representative photomicrographs of lung samples of the groups stained with HE and MT. A: Alveol; arrows, *. HE: Hematoxylin-eosin; MT: Masson's trichrome. 20X.

Data obtained from histological scoring were normally distributed as determined by the Kolmogorov-Smirnov test and, therefore, were analyzed with one-way ANOVA followed by post hoc Holm-Sidak testing. Statistical calculations were performed using Sigma Stat for Windows, version 3.0 (Jandel Scientific, San Rafael, CA); ( $<<0.001)$ was considered to be significant.

\section{RESULTS}

\section{Pulmonary Histopathology}

Control group (G1) demonstrated normal pulmonary architecture with thin alveolar septa and distinct respiratory bronchioles, alveolar sacs, and alveoli (Figure 3; A and B) (Graph 1). On the other hand microscopically findings in the lung speci- 


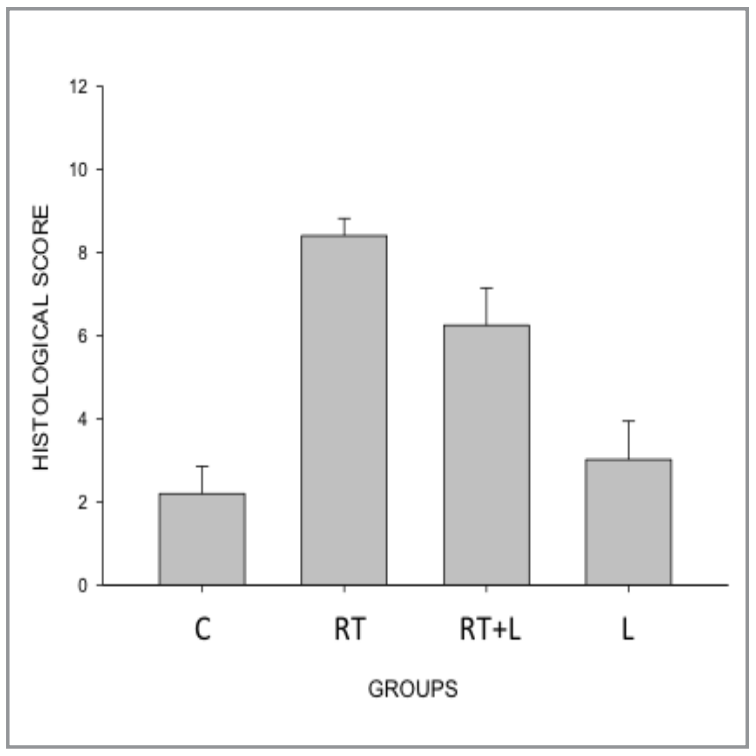

Graph 1. Lung injury score analysis of experimental groups. ${ }^{*} p \leq 0.001$ vs. both control and lapatinib groups. Bars represent mean \pm SEM.

mens displayed severe lung injury in group 2 inflammatory cell infiltration and increased amount of collagen fibrils in the interstitial area which eventually leaded to thickening of the interalveolar septa and shrinkage of the size of the alveoli. Most of the alveoli were collapsed, and some of the alveoli and alveolar sacs showed compensatory dilatation. Alveolar septa were significantly thicker than the control group (G1) ( $\mathrm{p}<0.001)$. (Figure 3; C and D) (Graph 1). Small focal fibrous masses were observed in some areas of the lungs in this group. Radiotherapy damaged the lung architecture.

The group which lapatinib treatment is given alone (G3) showed minimal infiltration of inflammatory cells and alveolar septal thickening which were negligible, since there were no statistically significant difference when the scores of the group were compared with those of the control group (Figure 3; E and F) (Graph 1).

The histopathological findings in the group which lapatinib treatment was given together with radiotherapy (G4) was similar to those in G2. Thus, lapatinib when administered concurrently with radiotherapy, did not further augment fibrosis in the lungs and did not impaired the lung damage. Further, similar to the animals in the radiotherapy group, animals in the radiotherapy + lapatinib group had significantly higher total lung injury scores than those in the control (G1) and lapatinib (G3) groups ( $p<0.001)$ (Figure 3; G and H) (Graph 1).

\section{DISCUSSION}

Breast cancer, is usually associated with an increase of activation of EGFR tyrosine kinases. Lapatinib is an oral tyrosine kinase inhibitor (TKI) that acts intracellulary directly targeting the tyrosine kinase domain of both ErbB-1 and ErbB2 receptors.

A preclinical study ${ }^{16}$, mice bearing xenografts of EGFR + and HER2 + breast cancer cells were treated with lapatinib and fractionated radiotherapy suggested that lapatinib combined with fractionated radiotherapy might be useful against EGFR+ and HER2+ breast cancers by inhibition of downstream signalling ERK1/2 and AKT correlates with sensitization in EGFR + and HER2 + cells. Although lapatinib sensitise breast cancer cells to radiation, we can not obtain any information regarding the toxicity.

A phase I study (EGF10004) $)^{17}$, L was administered in 67 patients pretreated with ERB1or HER2 overexpressing metastatic cancer. L was given at doses ranging from 500-1600mg once daily. The most frequent adverse events were diarrhea (42\%) and skin rash (31\%). The EGF10003 ${ }^{18}$ study with a daily dosage range of 500-900 $\mathrm{mg}$ bid had a similar result as a grade 1-2 gastrointestinal events and rash. In Japan phase I study ${ }^{19}$ was designed at doses of 900-1800 $\mathrm{mg}$ and the maximum tolerated dose was $1.800 \mathrm{mg}$ daily, 2 patients had grade 2 diarrhea and 1 had grade 1 GGT elevation. These phase I studies recommended that the optimum dose of lapatinib was $1.500 \mathrm{mg}$ daily. Perez et al..$^{20}$ analyzed the cardiac function data of 2,812 patients treated with lapatinib, the incidence of left ventricular ejection fraction decrease was $1.3 \%$ and were rarely symptomatic and generally reversible.

TKI's are small molecules pass the cell membrane and inhibit several intracellular tyrosine kinases and several growth factor receptors. Up to now there hasn't been approved TKI for the simultaneous use with radiotherapy. All combined toxicity are limited to case reports or studies with small 
numbers of patients. There are limited studies using lapatinib in combination with radiotherapy. Harrington et al. ${ }^{21}$ studied about lapatinib in combination with chemoradiotherapy in patients with locally advanced squamous cell carcinoma of the head and neck patients. Thirty-one patients were enrolled onto escalating lapatinib dose $(500,1000$ and $1500 \mathrm{mg} /$ day) and received the same dose of lapatinib plus radiotherapy 66 and $70 \mathrm{~Gy}$ and cisplatin $100 \mathrm{mg} / \mathrm{m}^{2}$ on days 1,22 and 43 . The most common grade 3 to 4 adverse events were radiation mucositis, radiation dermatitis, lymphopenia and neutropenia. There was no drug-related cardiotoxicity and interstistial pneumonitis were reported. Adding lapatinib to cisplatin-based chemoradiotherapy did not aggravate cisplatin-induced nausea or vomiting and lapatinib did not enhance radiation mucositis with grade 3 or higher in seen in $35 \%$ of patients. Although there is information regarding the combination of radiotherapy with lapatinib in head and neck cancer patients. No data exists regarding the combination of lapatinib with radiotherapy in breast cancer patients Bese et al. ${ }^{22}$ also did not show any increased effect of HER 2 monoclonal antibody trastuzumab on radiation induced lung fibrosis when combined with radiotherapy .

Targeted drugs are promising therapeutic candidates with a comparatively low toxicity profile. The risk of parallel use of both radiotherapy has not usually been studied.. In this experimental study, it was found that concomitant addition of lapatinib to thoracic radiation did not increase radiation induced pulmonary fibrosis in rats. Further work is needed to prioritize biomarkers for disease-directed studies, and underscores the need for improved trial design strategies in concomitant use of lapatinib with radiotherapy in breast cancer.

\section{Summary}

The lung is one of the most radiosensitive organ, yet is frequently irradiated as part of treatment for cancers of the breast. Lapatinib is a small-molecule tyrosine kinase inhibitor. There are limited studies using lapatinib in combination with radiotherapy. In this experimental study we found that concomitant addition of lapatinib to thoracic RT did not increase radiation induced pulmonary fibrosis in rats.

\section{REFERENCES:}

1. Karasawa K, Katsui K, Seki K, et al. Radiotherapy with concurrent docetaxel for advanced and recurrent breast cancer. Breast Cancer 10: 268-274, 2004.

2. Suh WW, Schott AF, Hayman JA, et al. A phase I dose escalation trial of gemcitabine with radiotherapy for breast cancer in the treatment of unresectable chest wall recurrences. Breast J 10: 204-210, 2004.

3. Stone HB, Coleman CN, Anscher MS, McBride WH. Effects of radiation on normal tissue: consequences and mechanisms. Lancet Oncol 4: 529-536, 2003.

4. Finkelstein JN, Johnston CJ, Baggs R, Rubin P. Early alterations in extracellular matrix and transforming growth factor beta gene expression in mouse lung indicative of late radiation fibrosis. Int J Radiat Oncol Biol Phys 28: 621-631,1994.

5. Rodeman HP, Bamberg M. Cellular basis of radiation-induced fibrosis. Radiother Oncol 35: 83-90,1995.

6. Rubin P, Johnston CJ, Williams JP, et al. A perpetual cascade of cytokines post irradiation leads to pulmonary fibrosis. Int J Radiat Oncol Biol Phys 33: 99-109,1995.

7. Anscher MS, Kong FM, Andrews K, et all. Plasma transforming growth factor beta 1 as a predictor of radiation pneumonitis. Int J Radiat Oncol Biol Phys 41: 1029-1035,1998.

8. Holbro T, Hynes NE. ErbB reseptors: Directing key signaling networks throughout life. Annu Rev Pharmacol Toxicol 44: 195-217, 2004.

9. Sartor Cl. Epidermal growth factor family receptors and inhibitors: Radiation response modulators. Semin Radiat Oncol 13: 22-30, 2003.

10. Schmidt-Ullrich RK, Contessa JN, Lammering G, et al. ERBB receptor tyrosine kinases and cellular radiation responses. Oncogene 22: 5855-5865, 2003.

11. Rusnak DW, Lackey $\mathrm{K}$, Afflect $\mathrm{K}$, et al. The effects of the novel, reversible epidermal growth factor receptor/Erb B-2 tyrosine kinase inhibitor, GW2016, on the growth of human normal and tumor-derived cell lines in vitro and in vivo. Mol Cancer Ther 1: 85-94, 2001.

12. Geyer C, Forster J, Lindquist D, et al. Lapatinib plus capacitabine for HER-2 positive advanced breast cancer. N Engl J Med 355: 2733-2743, 2006.

13. Brunilde G, Diane P, Joulie LB, et al. Effect of Lapatinib on the outgrowth of metastatic breast cancer cells to the brain. $J$ Natl Cancer Inst 100: 1092-1103, 2008.

14. Downing L, Sawarynski KE, Li J, et al. A simple quantitative method for assessing pulmonary damage after $\mathrm{x}$ irradiation. Radiat Res 173: 536-44, 2010.

15. Ashcroft T, Simpson JM, Timbrell V. Simple method of estimating severity of pulmonary fibrosis on a numerical scale. J Clin Pathol 41: 467-70, 1988. 
16. Sambade MJ1, Kimple RJ, Camp JT, et al. Lapatinib in combination with radiation diminishes tumor regrowth in Her2 + and basal like /EGFR + breast tumor Xenografts. Int J Radiat Oncol Biol Phys 77: 575-581, 2010.

17. Burris HA 3rd, Hurwitz HI, Dees EC, et al. Phase I safely, pharmacokinetics, and clinical activity study of lapatinib (GW572016), a reversible dual inhibitor of epidermal growth factor receptor tyrosine kinases, in heavily pretreated patients with metastatic carcinomas. J Clin Oncol 23: 5305-5313, 2005

18. Versola M, Burris HA, Jones S, et al. Clinical activity of GW 572016 in EGR10003 in patients with solid tumors. Proc Am Soc Clin Oncol 22: 14S, 2004.

19. Minami H, Nakagawa K, Kawada K, et al. A phase I study of GW572016 in patients with solid tumors. Proc Am Soc Clin Oncol 22: 14S, 2004.

20. Perez EA, Byrne JA, Hammond IW, et al. Results of an analysis of cardiac function in 2812 patients treated with lapatinib. Proc Am Soc Clin Oncol 24: 18S, 2006.

21. Harrington KJ, El-Hariry IA, Holford CS, et al. Phase I Study of combination with chemoradiation in patients with locally advanced squamous cell carcinoma of the head and neck. Lancet 27: 1100-1107, 2009.

22. Bese NS, Umay C, Serdengecti S, et al. The impact of trastuzumab on radiation-induced pulmonary fibrosis:Results of an experimental study. Med Oncol 27: 1415-9, 2010.

\section{Correspondence:}

Dr. Ozlem YETMEN DOGAN

Saglik Bilimleri Universitesi,

Kartal Dr. Lutfi Kirdar Egitim ve Arastirma Hastanesi

Radyasyon Onkolojisi Anabilim Dali

ISTANBUL / TURKEY

Tel: (+90-533) 2262674

Fax: (+90-216) 3520083

e-mail: dryetmen@gmail.com 